\title{
CONDIÇÕES DE PRODUÇÃO DE LEITE EM PROPRIEDADES FAMILIARES LOCALIZADAS NO MUNICÍPIO DE ALEGRE - ES, BRASIL
}

\author{
Conditions of milk production of family farms located \\ in the municipality of Alegre - ES, Brazil
}

\author{
Francisca Carvalho Nascimento Neta ${ }^{{ }^{*}}$, Mateus da Silva Junqueira ${ }^{2}$, \\ Joel Camilo Souza Carneiro², Maria da Penha Piccolo Ramos ${ }^{2}$, \\ Fabrízio Raggi Abdallah ${ }^{1}$, Camila Pereira Fracalossi ${ }^{2}$
}

\begin{abstract}
RESUMO
Objetivou-se avaliar as condições e práticas de produção de leite empregadas por proprietários rurais, bem como as condições de armazenamento e das instalações e estruturas dos locais de instalação de quatro tanques de refrigeração coletivos do município de Alegre, ES. Coletaram-se dados sobre procedimentos de higienização e estrutura física do estábulo, origem e tratamento da água, higiene e saúde dos manipuladores, procedimentos de higienização e assepsia dos tetos e controle sanitário do rebanho. Foi avaliada também a estrutura física dos locais dos tanques. Verificou-se que os currais eram arejados, secos e cobertos e que a minoria possuía piso cimentado e sala de ordenha. Um baixo percentual dos produtores realizava o pré $(21 \%)$ e o pós-dipping (6\%). Apenas $25 \%$ dos produtores realizavam o teste da caneca de fundo preto. Todos os equipamentos eram lavados após a ordenha, mas apenas $5 \%$ utilizavam sanitizantes e $94 \%$ das propriedades usavam água não tratada. Apenas $8 \%$ dos ordenhadores tinham o hábito de lavar as mãos antes da ordenha e $9 \%$ tinham conhecimento sobre a IN 62 do Ministério da Agricultura, Pecuária e Abastecimento. Nenhuma instalação possuía proteção contra entrada de insetos, roedores e contaminantes ambientais e eram mal dimensionadas, não permitiam a aplicação de medidas sanitárias adequadas, portanto, apresentavam condições
\end{abstract}

1 Instituto Capixaba de Pesquisa, Assistência Técnica e Extensão Rural (INCAPER), Avenida Olívio Corrêa Pedrosa, 556, 29500-000, Alegre, ES, Brasil. E-mail: francarvalho.neta@hotmail.com

2 Universidade Federal do Espírito Santo (UFES), Campus Alegre, Alegre, ES, Brasil.

* Autor para correspondência.

Recebido / Received: 07/07/2014

Aprovado / Approved: 17/09/2015

Rev. Inst. Laticínios Cândido Tostes, Juiz de Fora, v. 70, n. 3, p. 117-131, mai/jun, 2015 
higiênicas deficitárias. $\mathrm{O}$ alto grau de não conformidades relativo às boas práticas de produção de leite reforçou a necessidade de implementação das Boas Práticas Agropecuárias nas propriedades rurais para fins de obtenção de leite de acordo com os padrões de qualidade, prevenção de perdas e sustentabilidade da atividade leiteira da região.

Palavras-chave: leite cru; higiene; qualidade; segurança dos alimentos; ordenha manual.

\begin{abstract}
The present study aimed to assess the conditions and practices of production of raw milk used by farmers, as well as the conditions of storage and of the facilities and structures of the locations of the four collective cooling tanks, in the municipality of Alegre - ES. Data on sanitization procedures and physical structure of barns, source and treatment of water, hygiene practices and health status of milkers, udder cleaning and disinfection procedures and sanitary control of the herd was collected. The physical structure of the locations of the tanks was also assessed. The barns were ventilated, protected from moisture and had covers, and few had cemented floor and milking parlor. A low percentage of producers performed pre $(21 \%)$ and post $(6 \%)$ dipping procedures. Only $1 / 4$ of the farmers used the mug test. All equipment and tools were washed after milking, but few farmers (5\%) used sanitizers and $94 \%$ of the farms used untreated water. Only $8 \%$ of the milkers had the habit of washing their hands before milking, and $9 \%$ of them were aware of IN 62 regulation of the Ministry of Agriculture, Livestock and Supply. None of the facilities had protection against the entrance of insects, rodents and environmental contaminants. They were poorly sized, did not allow the application of adequate sanitary measures and sanitary conditions were deficient. The high level of nonconformities regarding good manufacturing practices for milk production reinforced the need for the implementation of Good Agricultural Practices in rural farms for the purpose of obtaining milk produced according to the quality standards, preventing losses and ensuring the sustainability of dairy production in the region.
\end{abstract}

Keywords: raw milk; hygiene; quality; food safety; manual milking.

\section{INTRODUÇÃO}

Tendo em vista a importância econômica da cadeia produtiva do leite no Brasil e os problemas relacionados à sua obtenção com boa qualidade, o Ministério da Agricultura, Pecuária e Abastecimento (MAPA) aprovou a Instrução Normativa $n^{\circ}$ 62, de 29 de dezembro de 2011, que entrou em vigor em janeiro de 2012 para as regiões Sul e Sudeste. Nessa legislação estão escalonados os prazos de vigência para que sejam atingidos os padrões físico-químicos e microbiológicos, de contagem de células somáticas e de resíduos químicos exigidos para o leite cru refrigerado, além de exigir a refrigeração do leite logo após a ordenha e na própria propriedade, bem como o seu transporte a granel até os laticínios (BRASIL, 2011).

No Brasil, ainda é significativa a obtenção de leite em condições de higiene inadequadas nas propriedades rurais, fator que 
compromete a qualidade do leite cru, com implicações na saúde pública, aceitabilidade e valor nutricional (ORTOLANI et al., 2010; OLIVEIRA et al., 2011; HILL et al., 2012). Caso não sejam empregadas práticas adequadas, são várias as possibilidades de contaminação do leite cru, como o contato do produto com o ar, solo, poeira, fragmentos de ração, esterco, insetos, utensílios mal higienizados, além da conduta higiênica inadequada do ordenhador (SILVA, 2008). A saúde da glândula mamária, a sanidade do rebanho, o ambiente em que os animais ficam alojados, a qualidade microbiológica da água e os procedimentos de higiene pessoal e dos equipamentos são fatores que afetam diretamente a qualidade da microbiota no leite cru (ARCURI et al., 2008).

A pecuária de leite é uma atividade de grande expressão socioeconômica no Brasil e no estado do Espírito Santo-ES. Essa atividade contribui para um dos principais setores do agronegócio na geração de renda e arrecadação tributária e em 2012 o estado produziu em torno de 400 milhões, o que representou 1,4\% do volume nacional (IBGE, 2015). No estado, grande parte da produção $(80 \%)$ é fornecida por Agricultores Familiares ${ }^{1}$, com produção média diária inferior a 100 litros. A cidade de Alegre - ES possui a atividade leiteira como sustentabilidade econômica e social da da maioria da população rural ativa, com 1.368 propriedades cadastradas no Instituto de Defesa Agropecuária e Florestal do Espírito Santo - IDAF, com uma população bovina de 65.242 animais (IDAF, 2013). No município, a produtividade anual, por vaca leiteira, é próxima a 2.367 litros/ano. A atividade leiteira é desenvolvida em sua grande maioria por agricultores familiares, com hábitos culturais que passam de pai para filho. O produto é originado de uma pecuária leiteira tradicional e são poucos animais em fase de lactação por propriedade (IDAF, 2013). A produção de leite em Alegre em 2013 foi da ordem de 16,2 milhões de litros (IBGE, 2015). Por meio de visitas técnicas anteriormente em algumas propriedades rurais, observaram-se não conformidades no manejo empregado na obtenção e armazenamento do leite cru.

Objetivou-se avaliar as condições e práticas de produção de leite empregadas pelos proprietários rurais, bem como avaliar as condições de armazenamento e das instalações e estruturas dos locais em que estão alojados quatro tanques de refrigeração coletivos do município de Alegre-ES.

\section{MATERIAL E MÉTODOS}

Realizou-se inicialmente, no período de fevereiro a junho de 2012, o cadastramento de 34 produtores rurais voluntários, por meio de visita técnica e aplicação de questionário estruturado (NETA, 2013), com base nas exigências da legislação vigente (BRASIL, 2011).

Os produtores foram convidados a participar da pesquisa, e aqueles que concordaram assinaram o termo de consentimento livre e esclarecido. Participaram produtores de quatro comunidades diferentes localizadas no município de Alegre-ES, nas quais tinham instalado um tanque de refrigeração coletivo. Eles foram identificados como: comunidade A (Tanque 1), comunidade B (Tanque 2), comunidade $\mathrm{C}$ (Tanque 3 ) e comunidade $\mathrm{D}$ (Tanque 4), com 6 propriedades na comunidade $A$, 12 na comunidade $\mathrm{B}, 5$ na comunidade $\mathrm{C}$ e 11 na comunidade D. O questionário continha perguntas relacionadas às práticas empregadas

1 Agricultores Familiares são aqueles agricultores inseridos no Programa Nacional de Fortalecimento da Agricultura Familiar, segundo a Lei n 11.326, de 24 de julho de 2006. 
para obtenção do leite cru antes, durante e após o processo de ordenha, como tipo de ordenha; volume de produção leiteira diária e mensal; origem da água utilizada; limpeza do estábulo; limpeza de equipamentos e tetos; asseio do ordenhador; horário das ordenhas; higienização e sanitização dos equipamentos; destino do leite; armazenamento pós-coleta; saúde do pessoal; e controle sanitário do rebanho para mastite, endoparasitas e ectoparasitas.

Aplicou-se também um questionário estruturado aos colaboradores responsáveis pela recepção e estocagem de leite nos quatro tanques de refrigeração coletivos, para verificação de conformidades ou não dos procedimentos. Os dados foram analisados com base na frequência relativa (\%) das respostas. Os resultados apresentados por meio de gráficos.

\section{RESULTADOS E DISCUSSÃO}

\section{Condições e práticas de obtenção do leite no município de Alegre-ES}

Constatou-se que o percentual do número dos analfabetos e daqueles com ensino fundamental incompleto correspondeu a $65 \%$ do total dos entrevistados e que apenas 3\% possuíam ensino superior completo (Figura 1).
Verificou-se que a baixa escolaridade é um fator limitante ao acesso às informações pertinentes à atividade leiteira, o que contribui para a prática de uma pecuária tradicional, com hábitos culturalmente arraigados, e dificuldades de adoção de boas práticas de produção. Esses resultados são semelhantes aos observados por Carvalho et al. (2014) em entrevistas com dez proprietários rurais no município de Rio Bonito-RJ, em que 50\% dos entrevistados tinham até o quinto ano do ensino fundamental, $20 \%$ estavam entre o sexto e o nono ano, $20 \%$ tinham o ensino médio completo e apenas $10 \%$ com o nível técnico concluído. Esses autores também concluíram que a escolaridade teve influência sobre as práticas higiênico sanitárias adotadas para a ordenha.

Picoli et al. (2014) ao aplicarem questionário a 274 produtores de leite do Rio Grande do Sul e avaliarem a relação entre as características de produção de leite empregadas nas propriedades e o grau de instrução dos produtores, além de qualidade microbiológica do produto, verificaram que a contagem de células somáticas foi significativamente menor nas amostras de leite produzido em propriedades onde os colaboradores tinham maior escolaridade, além da melhor manutenção dos equipamentos de ordenha. Os autores concluíram que o grau de

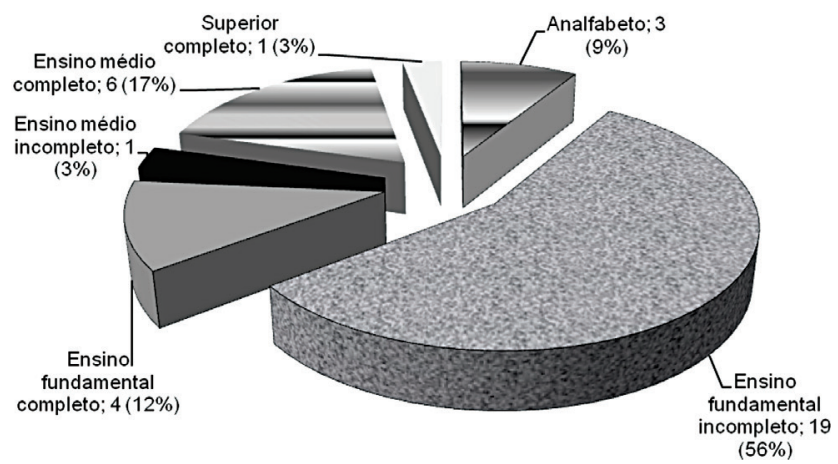

Figura 1 - Grau de escolaridade de produtores rurais em quatro comunidades de Alegre - ES 
escolaridade dos produtores teve um papel fundamental na adoção das boas práticas nas propriedades e com isso produzir leite de alta qualidade.

Khan; Silva (2005) ressaltaram a importância da implantação de escolas públicas no setor rural, a fim de possibilitar conhecimentos em todos os níveis e oferecer condições de competir em igualdade com outros setores produtivos, ao avaliarem pequenos produtores rurais beneficiados pelo Projeto São José, no Estado do Ceará. De acordo com estes autores, maior grau de escolaridade contribui favoravelmente para diminuir os problemas relativos a saneamento básico e a doenças. Da mesma forma, Vicente (2004) verificou a eficiência da produção agrícola no País e ressaltou que a educação influenciou e contribuiu para o aumento da eficiência na produção e na qualidade de vida da população.

Em relação à estrutura física, observouse que $100 \%$ dos currais possuíam cobertura e $79 \%$ tinham piso cimentado e em contrapartida, $85 \%$ dos produtores possuíam curral com parede à meia altura. Já $91 \%$ dos entrevistados mantinham o ambiente de sala de ordenha seco e limpo, tendo sido constatado que $100 \%$ dos locais visitados eram arejados e distantes de pocilgas e aviários. A origem da água utilizada no processo de ordenha em $82 \%$ das propriedades era de nascente; $3 \%$, de poços; $15 \%$, de córrego; e $94 \%$ delas não faziam nenhum tipo de tratamento da água. Entre as propriedades visitadas, 97\% dos produtores realizavam ordenha manual e 3\%, ordenha mecânica. Santos; Fonseca (2007) e Guerreiro et al. (2005) destacaram que a tecnologia empregada na ordenha não significava, necessariamente, que leite era de melhor qualidade microbiológica, já que suas tubulações podem conter focos de contaminação bacteriana se mal higienizadas são frequentes, em diversas regiões do Brasil, resultados semelhantes aos constatados no presente estudo no que se refere às condições higiênicas de obtenção do leite. Carvalho et al. (2014) constataram que, em dez propriedades avaliadas quanto aos procedimentos do manejo sanitário na ordenha e pós-ordenha, apenas 20\% utilizavam água corrente clorada na origem; nas demais propriedades $(80 \%)$ utilizava-se água de poço não tratada. Em relação à higiene pessoal, 100\% dos produtores não a realizavam adequadamente na região de Rio Bonito, RJ.

Em trabalho realizado por Gonçalves et al. (2014) no município de Sales de Oliveira, SP, os autores concluíram que antes da implementação das Boas Práticas na propriedade avaliada, a ordenha era realizada sem as condições de higiene necessárias, bem como as instalações, ou seja, todas as estruturas físicas que pertenciam à propriedade como depósitos diversos e salas e galpões apresentavam-se precárias e desorganizadas e não recebiam os cuidados de limpeza compatíveis com a produção de leite com qualidade higiênico-sanitária exigida. Além disso, o rebanho era composto por animais mestiços com cruzamentos de raças zebuínas sem o adequado controle sanitário exigido e não havia o acompanhamento dos programas de vacinações e vermifugações que eram necessários.

Ramos et al. (2014) avaliaram quatro comunidades rurais, denominadas de A, B, C e D constituídas de vinte e oito propriedades localizadas no município de São Mateus, ES e constataram alto percentual de inadequações nos requisitos de estrutura física do estábulo. Observou-se na comunidade A, que $50 \%$ dos produtores realizavam a limpeza do estábulo diariamente e $50 \%$ semanalmente, enquanto na comunidade D, $100 \%$ da limpeza era realizada diariamente. Constatou-se com relação à estrutura física do estábulo, que 2 $(100 \%)$ dos produtores da comunidade rural D possuíam o estábulo coberto, enquanto que nas comunidades $\mathrm{A}, \mathrm{B}$ e $\mathrm{C}$ os valores 
foram de $25 \%, 75 \%$ e $60 \%$, respectivamente. Observou-se que $100 \%$ dos produtores das comunidades A e D não possuíam o piso cimentado dos estábulos, enquanto que nas comunidades B e C os valores foram de $67 \%$ e $90 \%$ respectivamente. Observou-se que em $100 \%$ das comunidades A e D os estábulos não eram cercados, enquanto que nas comunidades B e C foram de $75 \%$ e $80 \%$ respectivamente. Além disso, em relação ao estábulo ser arejado e sem ventos fortes, observou-se que 25\% dos produtores da comunidade A e $100 \%$ da comunidade B atendiam a essas condições, enquanto que nas comunidades $\mathrm{C}$ e $\mathrm{D}$ os valores foram de $80 \%$, e $100 \%$ respectivamente. Com relação aos estábulos serem secos, limpos e com ligeiro declive, observou-se que $100 \%$ dos produtores da comunidade A e D não atenderam a essas condições, enquanto que nas comunidades $\mathrm{B}$ e $\mathrm{C}$ os valores foram de $58 \%$ e $90 \%$ respectivamente. Observou-se que $75 \%$ das propriedades da comunidade $\mathrm{D}$, os estábulos situavam-se distantes de pocilgas e aviários, enquanto que nas comunidades $\mathrm{A}, \mathrm{B}$ e $\mathrm{C}$ os valores foram de $83 \%, 90 \%$ e $100 \%$ respectivamente. Observou-se que em $28(100 \%)$ das propriedades rurais não era realizado o procedimento de pré-dipping e pós-dipping e o tipo de ordenha era manual.

Ramos et al. (2013) constataram que somente $40 \%$ dos ordenhadores lavavam as mãos e antebraços antes da ordenha e $13 \%$ usavam soluções antissépticas após avaliarem este procedimento de higiene em 30 propriedades rurais do município de São Mateus-ES. Apenas 4\% dos ordenhadores realizavam os exames periódicos de saúde, e nenhuma das propriedades empregava os procedimentos de pré-dipping e pós-dipping. O controle da mastite por meio da utilização do teste da caneca de fundo preto não era feito em $94 \%$ das propriedades, e em $100 \%$ não era realizado o Califórnia Mastite Teste (CMT). No tocante à qualidade da água utilizada para higienização dos equipamentos e dos utensílios de ordenha e do ambiente, apenas $17 \%$ das propriedades recebiam tratamento adequado. O alto grau de não conformidades constatado nas propriedades compromete a qualidade e a inocuidade do leite cru e dos produtos lácteos.

Os resultados deste estudo são semelhantes aos de Silva et al. (2009). Esses autores observaram, em propriedades rurais do município de São Mateus-ES, baixo grau de atendimento aos requisitos de boas práticas de produção. Quanto à estrutura física, 53\% tinham cobertura, $90 \%$ não possuíam piso cimentado e nenhum estábulo apresentava parede à meia altura, o que descaracteriza o ambiente de uma sala de ordenha. Entre os produtores, $60 \%$ não consideraram o ambiente seco e limpo, embora $100 \%$ dos ambientes visitados fossem arejados e distantes de fontes de mau cheiro. No item referente à limpeza do estábulo e equipamentos, em $80 \%$ das propriedades não era realizada a limpeza diária no estábulo. Os equipamentos (100\%) eram limpos logo após a ordenha, mas apenas $43 \%$ das propriedades utilizavam produtos sanitizantes.

Os resultados do controle sanitário do rebanho são apresentados na Figura 2. Observou-se que todos os produtores $(100 \%)$ vacinavam o rebanho contra febre aftosa. O controle de endoparasitos e ectoparasitos é indispensável na produção leiteira, a qual depende da sanidade do animal para a produção e também para a qualidade do produto e, consequentemente, para a geração de renda das propriedades rurais (CENAGRI, 2004).

Em outros estudos são relatadas falhas no controle sanitário do rebanho. Ramos et al. (2014), observaram a existência de preocupação por parte dos vinte e oito produtores rurais (100\%) avaliados no município de São Mateus, ES com a ocorrência de mastite clínica e, dessa forma, faziam a verificação constante do aspecto externo do úbere das 
vacas com presença como inchaço e vermelhidão e verificaram que em nenhuma das propriedades realizavam testes específicos para diagnóstico de mastite clínica (teste da caneca de fundo preto) ou sub-clínica $(\mathrm{Ca}-$ lifórnia Mastite Teste (CMT). Este fato compromete a obtenção de leite em relação à inocuidade e qualidade e coloca em risco a saúde da população. Em outras pesquisas de diagnóstico realizadas por (ARCURI et al., 2008; NERO et al., 2009; PEDRICO et al., 2009) também foram observados a falta de realização desses mesmos testes nos rebanhos.

Silva et al. (2009) constataram que apenas $6 \%$ dos produtores rurais faziam controle de mastite, apesar de não realizarem o Califórnia Mastite Teste (CMT); eles faziam uso da caneca de fundo escuro ou descarte do leite ao chão. O controle da aftosa e da raiva era realizado em $100 \%$ das propriedades, e 93\% faziam controle da brucelose. Apenas $16 \%$ realizavam o controle sistemático de tuberculose, e o controle de paratifo e carbúnculo sintomático era feito em $93 \%$ das propriedades rurais visitadas. A periodicidade do controle de ectoparasitas apresentou $20 \%$ com frequência quinzenal, $53 \%$ com frequência mensal e $20 \%$ em quatro vezes ao ano; $7 \%$ não realizavam o controle.

Nero et al. (2009) constataram que a maioria dos produtores rurais (41-68,3\%) não realizava o CMT como teste de triagem. Eles faziam o diagnóstico de mastite apenas pelo descarte dos primeiros jatos em caneca de fundo escuro $(43,2 \%)$ ou no chão $(9,1 \%)$. Todos os produtores realizavam a vacinação contra febre aftosa, porém apenas $19(31,7 \%)$ relataram vacinar contra carbúnculo e 7 $(11,7 \%)$ contra raiva.

De acordo com Pedrico et al. (2009), embora os produtores rurais do município de Araguaína-TO conheçam o Programa de Controle e Erradicação da Brucelose e Tuberculose preconizado pelo Ministério da Agricultura, Pecuária e Abastecimento (MAPA), esses não realizavam os testes de diagnósticos para essas zoonoses, mesmo em casos suspeitos. Diante dessa situação, esses autores salientaram a necessidade de manter o rebanho saudável para obtenção de leite com alto padrão de qualidade.

$\mathrm{O}$ volume diário de leite produzido nas propriedades rurais variou de menor ou igual a 100 L $(94,1 \%)$ a 200 litros diários $(6 \%)$.
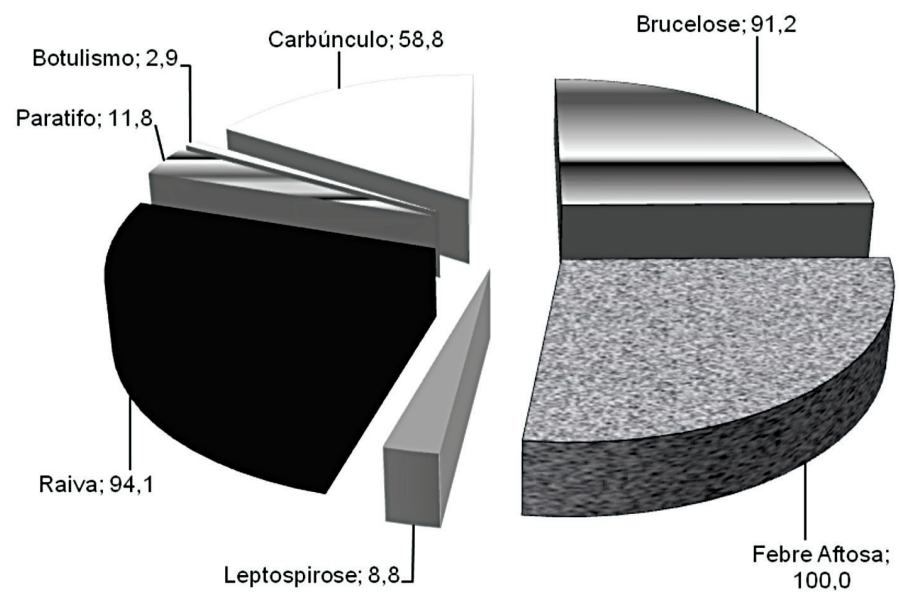

Figura 2 - Resultados de vacinação (\%) do gado leiteiro em quatro propriedades rurais localizadas no município de Alegre - ES 
O leite era estocado em tanque de refrigeração coletivo, e a condução da ordenha era realizada nas propriedades rurais, em horários fixos estabelecidos pelo produtor: em geral, das 5 às 8 horas. Na Figura 3 é apresentado um gráfico relativo ao tempo de resfriamento do leite.

O intervalo máximo entre a condução da ordenha e o resfriamento do leite foi de 30 minutos para $97 \%$ dos produtores rurais, e o período máximo de permanência do leite no tanque de refrigeração foi de 48 horas. Esse fator é determinante para a prevenção de alterações físico-químicas no leite.

Observou-se neste estudo que em $76 \%$ das propriedades não era realizado o teste da caneca de fundo preto, com relatos da ocorrência de mastite em $32 \%$ do rebanho. Todos os entrevistados faziam o tratamento com antibióticos, dos quais $64 \%$ não respeitavam o período de carência. Com relação à higienização dos animais, 53\% higienizavam os tetos e úbere; apenas $21 \%$ realizavam o pré-dipping; e apenas $6 \%$ realizavam o pós-dipping. O hábito de secar o úbere e tetos antes da ordenha era adotado por apenas 53\% dos entrevistados; destes, $30 \%$ utilizavam papel-toalha e $23 \%$ o faziam por intermédio de panos, procedimento não permitido pela legislação, considerando que o uso de tecido para esse fim contribui para disseminação de microrganismos causadores de mastite entre os animais do rebanho. A secagem completa dos tetos após o pré-dipping com papel-toalha descartável é importante, devido ao risco de contaminação do leite pelo uso de sanitizantes.

A adoção dos procedimentos recomendados pela legislação para produção de leite é importante, pois contribui para a manutenção da qualidade e inocuidade do leite. Deve-se considerar que tetos com sujidades podem contaminar o leite, com consequente aumento da acidez e aceleração do processo de deterioração. O teste da caneca possibilita a identificação rápida de animais com mastite clínica, e essa doença é associada à perda produtiva e econômica e a prejuízos maiores, como a perda dos tetos ou, até mesmo, o descarte do animal.

Resultados semelhantes a este estudo foram observados por Camargo et al. (2014)

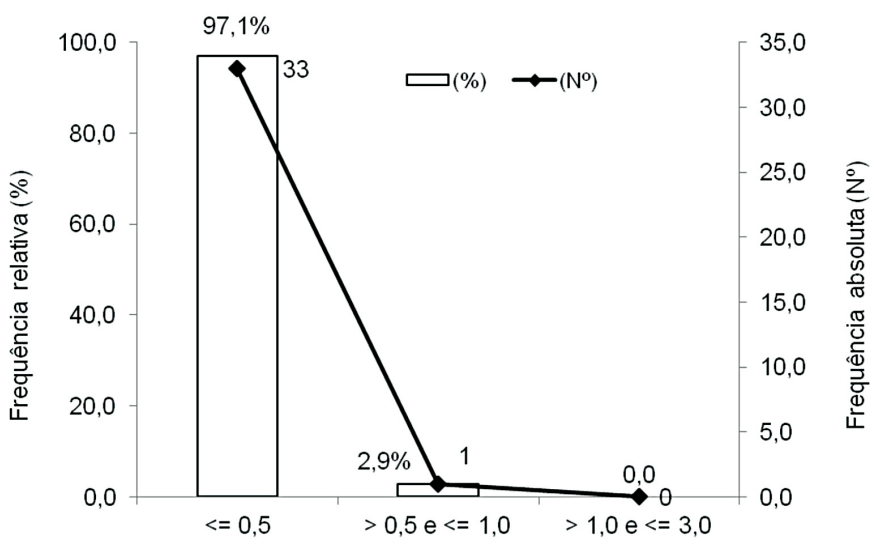

Tempo pós-ordenha até o resfriador (horas)

Figura 3 - Tempo para entrega do leite nos locais de instalação dos tanques de refrigeração após a ordenha em Alegre - ES 
ao avaliarem as condições de produção e estocagem do leite cru em 75 propriedades rurais em três regiões do estado de São Paulo. Eles concluíram que $77,3 \%$ das propriedades avaliadas apresentaram condições inadequadas para produção de leite assim como higienização inadequada empregada nos equipamentos e utensílios utilizados os quais certamente compromete a qualidade de leite e derivados.

Em estudos realizados em outros estados brasileiros também é relatado o alto grau de não conformidades na produção de leite. Carvalho et al. (2014), ao avaliarem os procedimentos de dez produtores rurais em Rio Bonito-RJ, constataram que somente $10 \%$ dos produtores faziam a higienização adequada dos tetos, 40\% utilizavam apenas água e os outros 50\% não realizavam nenhum tipo de higienização. Quanto à secagem dos tetos, $20 \%$ das propriedades a realizavam com uso de papel-toalha, 30\% utilizavam panos comuns para enxugar os tetos de todos os animais e os outros 50\% não enxugavam os tetos antes de iniciar a ordenha. Apenas $10 \%$ realizavam o pré-dipping, e $10 \%$ faziam somente o pós-dipping. Os demais produtores não realizavam nenhum procedimento, e em nenhuma das propriedades realizava-se o teste da caneca.

Da mesma forma, Mororó et al. (2010) observaram condições precárias de produção de leite caprino em 23 propriedades do município de Monteiro-PB. Esses autores verificaram que a higienização das instalações e equipamentos era feita em $60,9 \%$ dos casos, e, do total dos entrevistados, 17,4\% não realizavam a higiene do teto dos animais. Apenas em 8,7\% das propriedades usava-se papel toalha para enxugar o teto; a maioria $(65,2 \%)$ usava tecidos comuns para esse fim; e $26,1 \%$ não enxugavam. Em apenas $21,7 \%$ das propriedades realizava-se o CMT (Califórnia Mastite Teste); somente $34,8 \%$ realizavam o teste da caneca telada; e em nenhuma das propriedades realizava-se o pré-dipping, sendo o pós-dipping adotado em 8,7\% delas. Silva et al. (2009) também constataram não conformidades, como nos procedimentos de higienização dos animais. Apenas 17\% higienizavam os tetos e úbere, e somente $6 \%$ usavam produtos antissépticos. $\mathrm{O}$ hábito de secar o úbere e tetos antes da ordenha era adotado por apenas $7 \%$ dos entrevistados, e $100 \%$ dos que o realizavam o faziam com tecidos.

Constatou-se, no município de Alegre, que em todas as propriedades utilizavam-se vasilhames exclusivos para a ordenha. Entre os entrevistados, $65 \%$ alimentavam o animal durante a ordenha, $100 \%$ não possuíam o hábito de passar o rabo do animal no úbere e tetos e $65 \%$ realizavam o controle de insetos e roedores sempre que se fazia necessário. Apenas $60 \%$ dos produtores possuíam água no local, 37\% usavam detergentes comuns e apenas 3\% utilizavam soluções sanitizantes. A maioria dos ordenhadores (91\%) não adotava o hábito de banhar-se antes de realizar a ordenha; já 94\% mantinham as unhas aparadas, $73 \%$ dos ordenhadores lavavam as mãos e antebraço e não usavam soluções antissépticas, além de não usarem roupas específicas para ordenhar. Constatou-se também que $94 \%$ não possuíam o hábito de fumar durante a ordenha, 97\% não tinham o hábito de cuspir e escarrar durante a ordenha e 76\% não realizavam exames periódicos de saúde.

Hábitos higiênicos inapropriados empregados por ordenhadores são, com frequência, relatados em outros trabalhos de pesquisa. Silva et al. (2009) observaram que $94 \%$ dos ordenhadores não adotavam o hábito de banhar-se antes de realizar a ordenha; 6\% mantinham as unhas aparadas; $40 \%$ dos ordenhadores higienizavam as mãos e antebraços; e apenas 13\% usavam soluções antissépticas. Entre os proprietários rurais, 96\% não possuíam o hábito de fumar; $94 \%$ não tinham o hábito de cuspir e escarrar durante a ordenha; e $94 \%$ não realizavam exames 
periódicos de saúde. Da mesma forma, Pedrico et al. (2009) verificaram que 38\% não lavavam as mãos antes da ordenha e 67\% não usavam touca e boné antes do processo de obtenção do leite. Verificou-se também que, do total da produção de leite, 97\% era transportado dos tanques de refrigeração ao laticínio em caminhão isotérmico. Quanto ao uso de latões, $91 \%$ dos produtores adotavam o procedimento de usá-los e de mantê-los à sombra até serem destinados ao ponto de coleta (tanque de refrigeração) para descarga do leite. Dos produtores entrevistados, $71 \%$ dispunham os latões sobre estrados de madeira.

Silva et al. (2009) relataram que $93 \%$ dos produtores rurais enviavam o leite para um tanque de refrigeração próximo às propriedades rurais, e esse valor era destinado ao laticínio e transportado em caminhões isotérmicos em 48 horas após a ordenha. Contudo, 96\% dos produtores rurais que utilizavam latões para levar o leite até o tanque de refrigeração disseram que estes eram mantidos na sombra até o seu destino. Foi constatado também que, dos 30 produtores rurais entrevistados, apenas $7 \%$ processavam o leite na propriedade rural para fabricação de queijos, e nenhum produtor promovia a venda domiciliar do produto na região. Em trabalho realizado por Pedrico et al. (2009), em que foram visitadas 41 propriedades rurais, constatou-se que $40 \%$ do leite produzido no município de Araguaína-TO era destinado aos laticínios locais ou vendido na forma in natura para a população do município, e o restante era destinado ao consumo próprio, ou à fabricação de queijos, que posteriormente eram vendidos nas feiras populares da região.

Verificou-se que $91 \%$ dos entrevistados que não tinham recebido nenhum tipo de treinamento ou palestra sobre as normas instituídas pela $\mathrm{IN} \mathrm{n}^{\circ} 62$. Ao observar o percentual de $9 \%$ dos produtores treinados, verificou-se que $67 \%$ deles receberam treinamento de instituição pública e $33 \%$ de cooperativas. A principal dificuldade relatada pelos produtores de leite entrevistados para se adequarem à Instrução Normativa $n^{\circ} 62$ era a falta de capacitação em educação sanitária e qualidade do leite (Figura 4).

Para sanar essas deficiências, é preciso que as instituições de pesquisa, as cooperativas e os representantes de classe estejam mais próximos dos produtores para identificar as suas dificuldades e implementar conjuntamente um programa efetivo de desenvolvimento no setor pecuário com ênfase

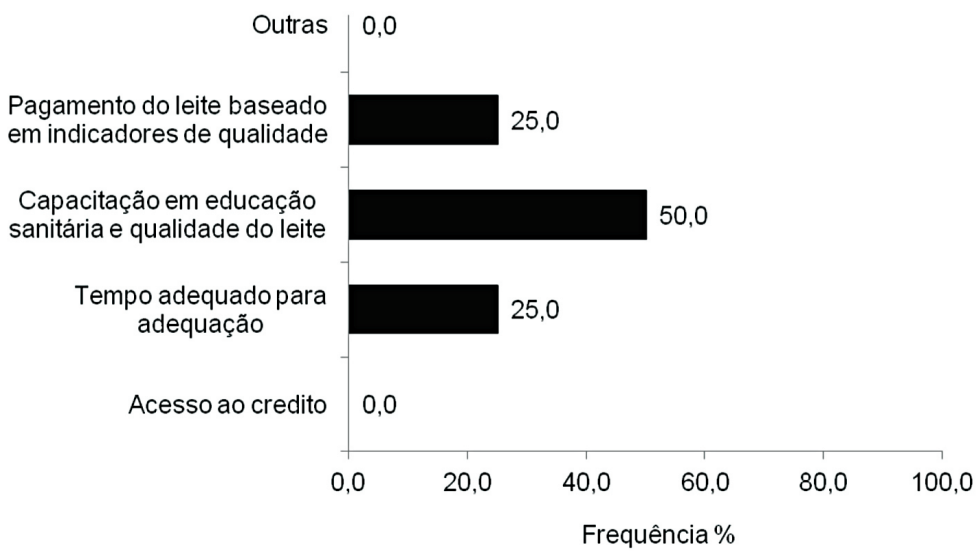

Figura 4 - Dificuldades relatadas por produtores rurais para adoção da IN no 62 em Alegre - ES 
na qualidade do leite. A implantação de boas práticas de ordenha e a adoção de recomendações adequadas para tratamento de mastite, além da manutenção e higienização dos equipamentos de ordenha, permitem redução considerável na contagem bacteriana total e contagem de células somáticas e aumento do índice de aceitação, o que traz como consequência o aumento da renda dos produtores (BOZO et al., 2013).

A refrigeração do leite, na ausência de práticas que reduzam a contaminação, não tem efeito positivo sobre a qualidade do leite, considerando a possibilidade de seleção de bactérias psicrotróficas (SILVA et al., 2011).

Com relação aos resíduos sólidos, constatou-se neste trabalho que eram destinados, em $91 \%$ das propriedades, à adubação das capineiras, e os $9 \%$ restantes utilizavam-nos para compostagem. Já os efluentes corriam a céu aberto em $100 \%$ das propriedades rurais. A destinação inadequada dos dejetos contribuía para poluição ambiental, com liberação de odores fétidos, e a proliferação de microrganismos causava encharcamento do terreno. Isso contribui para provocar doenças de cascos nos animais e, consequentemente, prejuízos financeiros para o produtor, além da possibilidade de os efluentes alcançarem os cursos d'água do município de Alegre e provocarem contaminação química e microbiológica.

\section{Condições das instalações e tanques de refrigeração}

Com relação às instalações, em nenhum dos locais de instalação dos tanques de refrigeração observou-se a presença de proteção contra entrada de insetos e roedores, contaminantes ambientais e tanque para lavagem de latões e de utensílios de coleta. Esse resultado também é relatado por Nero et al. (2005), com a observação de que a adoção de medidas isoladas, como compra de tanques e aquisição de tecnologias, não é suficiente para a produção de leite de boa qualidade microbiológica.

Constatou-se que as estruturas físicas eram desprovidas de instalações básicas e mal dimensionadas e não permitiam a aplicação de medidas sanitárias de forma adequada e que as condições higiênicas eram extremamente deficitárias e prejudicavam a manutenção da qualidade do leite. No item referente ao uso dos equipamentos de refrigeração, verificouse que a produção diária de leite era enviada uma única vez por dia para o Tanque 2, o que pode ser indício de erro de manejo, e resultava em baixa produtividade; por outro lado, uma nova entrada de leite no tanque resultava em oscilações de temperatura e poderia contribuir para o aumento dos valores na contagem de microrganismos. Essas constatações são semelhantes às de Silva et al. (2010), que avaliaram a qualidade higiênico-sanitária do leite cru produzido em Umuarama-PR. Esses autores verificaram que a entrada constante de leite em temperatura ambiente no tanque de refrigeração contribuiu para a redução da eficiência da refrigeração e observaram também aumento nas contagens de todos os grupos de microrganismos em 24 horas, exceto $E$. coli e estafilococos coagulase positiva.

O procedimento recomendado pela IN $n^{\circ} 62$ (BRASIL, 2011) para a conservação do leite é que o tempo entre a ordenha e a coleta do leite não ultrapasse duas horas, quando componentes naturais do leite com atividade bactericida perdem a sua atividade. Além disso, um curto tempo de armazenamento, no período máximo de 48 horas, previne a multiplicação microbiana e altas contagens de bactérias psicrotróficas (PINTO, 2006). A utilização de tanques comunitários, que é uma alternativa para pequenos produtores, pode acumular falhas individuais, o que contribui para prejudicar a qualidade do leite refrigerado (BUENO, 2004).

No item referente aos procedimentos de controle de qualidade (PCQ), foi verificado 
que os trabalhadores responsáveis pelos tanques 1 e 4 receberam treinamento básico sobre higiene. Esse fato desqualificou os trabalhadores dos tanques 2 e 3 para identificar e controlar os pontos críticos que interferem diretamente na qualidade microbiológica do leite. Para alcançar a melhoria do padrão de qualidade do leite, é necessário investir na conscientização e no treinamento de pessoal, como melhoria da higiene de produção e adequada higienização de utensílios e equipamentos. Observou-se também que nos quatro tanques eram adotados procedimentos inadequados de higienização. A aplicação de boas práticas nos pontos de coleta - com base na lavagem e manutenção do tanque, das mangueiras e engates, e de latões, usando bucha, detergente neutro ou escovas, sanitizantes e água potável, além da limpeza diária do ambiente é um fator determinante para melhoria da qualidade do leite e sucesso na atividade.

Ao se verificar a higienização do trabalhador responsável pela recepção e estocagem do leite no ponto de coleta, observou-se que os trabalhadores não possuíam o hábito de banhar-se antes de iniciar as atividades, bem como de usar roupas específicas, procedimentos esses que viabilizam a transmissão de microrganismos presentes na superfície corporal e nas vestes, contaminando as superfícies de contato e, consequentemente, o leite. Outro fator preocupante foi a não realização de exames de saúde periódicos dos trabalhadores, que podem ser portadores assintomáticos de patogenias. Ao avaliar nas propriedades rurais o comportamento e o tratamento destinados aos recursos hídricos e ao meio ambiente, verificou-se que a água utilizada nos pontos de coleta provinha de poços e nascentes sem qualquer proteção contra o acesso de animais e poluentes e sem adoção de qualquer sistema de tratamento de água, tornando a sua origem duvidosa.

No ambiente, alguns microrganismos estão presentes na água, solo e cama dos animais, sendo capazes de provocar doenças em seres humanos pela ingestão do leite não pasteurizado, em condições especiais (FONSECA; SANTOS, 2000).

Constatou-se que os efluentes corriam a céu aberto, constituindo-se, assim, em fontes de contaminação dos mananciais de água por carrearem resíduos orgânicos, com consequente aumento da demanda bioquímica de oxigênio, e resíduos químicos usados no processo de lavagem geral. No item referente à seleção e transporte, observou-se maior número de atendimento aos requisitos instituídos pela legislação vigente; no entanto,

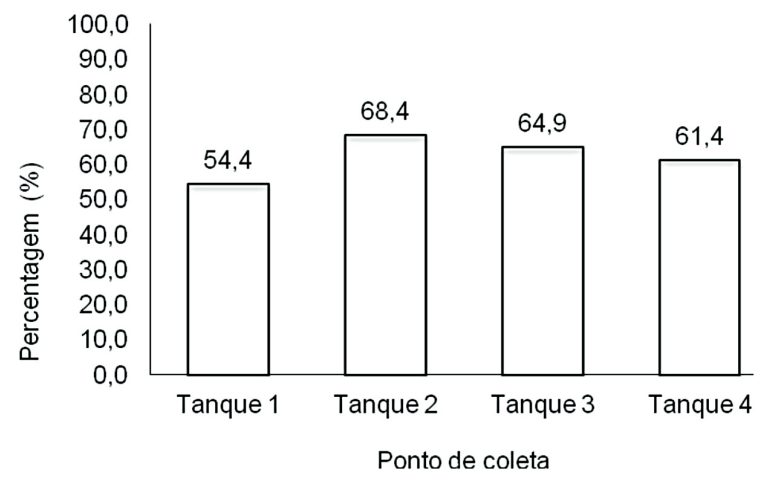

Figura 5 - Porcentagem de atendimento aos requisitos da IN no 62, por ponto de coleta do leite em Alegre - ES 
verificou-se que nos tanques 1 e 3 não se realizava a agitação do leite antes da coleta, o que pode comprometer os resultados das análises.

No item referente à assistência técnica, observou-se que os trabalhadores responsáveis pelos tanques 1, 2 e 4 receberam algum tipo de assistência técnica. Ficou evidente a importância e a necessidade de investir em treinamento e acompanhamento técnico para possibilitar a adoção das normas instituídas pela legislação sanitária vigente no País.

Na Figura 5 encontra-se o percentual de atendimento aos requisitos do Regulamento Técnico da Coleta de Leite Cru Refrigerado e seu Transporte a Granel, instituído pela IN $\mathrm{n}^{\circ} 62$ (BRASIL, 2011), para os quatro tanques de refrigeração.

Embora a maior porcentagem de atendimento aos itens da legislação vigente tenha sido observada no tanque 2 , constatou-se que ele apresentou-se fora do padrão estabelecido pela $\mathrm{IN}^{\circ}{ }^{\circ} 62$, o que indica deficiência higiênica na produção e necessidade de implementação das práticas sanitárias para fins de prevenção de contaminações.

Nos demais tanques, observou-se também alto percentual de não conformidades, $o$ que reforçou a ideia de que não é suficiente o esforço de elos isolados da cadeia produtiva, e sim que todos os envolvidos sejam capacitados e adotem medidas higiênico-sanitárias adequadas, além do controle efetivo da mastite, de forma que contribua para obtenção de leite dentro dos padrões exigidos.

\section{CONCLUSÕES}

O alto grau de não conformidades nas propriedades rurais, no que diz respeito às boas práticas de produção de leite, indicou a necessidade de realização de um esforço conjunto das pessoas envolvidas na sua cadeia produtiva, no sentido de implementar e adotar as Boas Práticas Agropecuárias nas propriedades rurais, de forma a contribuir para a melhoria da qualidade do leite e garantir a sustentabilidade do setor leiteiro no município de Alegre, região sul do Espírito Santo.

\section{REFERÊNCIAS}

ARCURI, E. F. et al. Contagem, isolamento e caracterização de bactérias psicrotróficas contaminantes do leite cru refrigerado. Ciência Rural, v. 38, n. 8, p. 2250-2255, 2008.

BOZO, G. A. et al. Adequação da contagem de células somáticas e da contagem bacteriana total em leite cru refrigerado aos parâmetros da legislação. Arquivo Brasileiro de Medicina Veterinária e Zootecnia, v. 65, n. 2, p. 589594, 2013.

BRASIL. Ministério da Agricultura, Pecuária e Abastecimento. Instrução Normativa $n^{\circ}$ 62, de 29 de dezembro de 2011. Aprova o Regulamento Técnico de Produção, Identidade e Qualidade do Leite tipo A, o Regulamento Técnico de Identidade e Qualidade de Leite Cru Refrigerado, o Regulamento Técnico de Identidade e Qualidade de Leite Pasteurizado e o Regulamento Técnico da Coleta de Leite Cru Refrigerado e seu Transporte a Granel, em conformidade com os Anexos desta Instrução Normativa. Diário Oficial da República Federativa do Brasil, Brasília, 30 dez. 2011. Seção 1, p. 6.

BUENO, V. F. F. Contagem celular somática e bacteriana total do leite cru refrigerado em tanques de expansão de uso individual no Estado de Goiás. 200452 f. Dissertação (Mestrado em Ciência Animal) - Universidade Federal de Goiás, Goiânia, 2004.

CAMARGO, T. M. et al. Occurrence of Listeria monocytogenes, total coliforms, Escherichia coli, and production and storage processes of raw milk from dairy farms in the state of São Paulo, Brazil. African Journal 
of Microbiology Research, v. 8, n. 29, p. 2766-2771, 2014.

CARVALHO, E. C. et al. Avaliação da prática higiênico-sanitária na ordenha na região de Rio Bonito, Rio de Janeiro: uma abordagem qualitativa. Revista do Instituto de Laticínios Cândido Tostes, v. 69, n. 2, p 102-109, 2014.

CENAGRI. Curso de Bovinocultura Leiteira: normas técnicas. Brasília: CENAGRI, 2004.

FONSECA, L. F. L.; SANTOS, M. V. Qualidade do leite e controle de mastite. São Paulo: Lemos Editorial, 2000. 175 p.

GONÇALVES, A. C. S. et al. Assistência técnica e extensão rural: sua importância para a melhoria da produção leiteira. Relato de caso. Revista Brasileira de Higiene e Sanidade Animal, v. 8, n. 3, p. 47-61, 2014.

GUERREIRO, P. K. et al. Qualidade microbiológica de leite em função de técnicas profiláticas no manejo de produção. Ciência e Agrotecnologia, v. 29, n. 1, p. 216-222, 2005.

HILL, B. et al. Microbiology of raw milk in New Zealand. International Journal of Food Microbiology, n. 157, v. 2, p. 305$308,2012$.

INSTITUTO BRASILEIRO DE GEOGRAFIA E ESTATÍSTICA (IBGE). Censo Demográfico de 2010. Disponível em: $<$ http://www. ibge.gov.br>. Acesso em: 05 maio 2015.

INSTITUTO BRASILEIRO DE GEOGRAFIA E ESTATÍSTICA (IBGE). Pesquisa da Pecuária Municipal. SIDRA. Disponível em: <www.sidra.ibge.gov.br>. Acesso em: 05 maio 2015.

INSTITUTO DE DEFESA AGROPECUÁRIA E FLORESTAL DO ESPÍRITO SANTO
(IDAF). Relatório Anual de Bovinos Cadastrados no Município de Alegre-ES/2012. Alegre, 2013.

KHAN, S. A.; SILVA, R. M. L. Capital social das comunidades beneficiadas pelo Programa de Combate à Pobreza Rural - PCPR/Projeto São José - PSJ - Estado do Ceará. Revista de Economia e Sociologia Rural, v. 43, n. 1, p. 101-117, 2005.

MORORÓ, A. M. et al. Manejo sanitário da ordenha e qualidade do leite caprino: Estudo de caso de Unidade Produtora no Município de Monteiro - PB. In: CONGRESSO NORDESTINO DE PRODUÇÃO ANIMAL, 6.; SIMPÓSIO NORDESTINO DE ALIMENTAÇÃO DE RUMINANTES, 7.; FÓRUM DE COORDENADORES DE PÓS GRADUAÇÃO EM PRODUÇÃO ANIMAL DO NORDESTE, 1.; FÓRUM DE AGROECOLOGIA DO RIO GRANDE DO NORTE, 1., 2010, Mossoró. Anais... Mossoró: Sociedade Nordestina de Produção Animal; UFERSA, 2010. 1 CD-ROM.

NERO, L. A. et al. Leite cru de quatro regiões leiteiras brasileiras: perspectivas de atendimento dos requisitos microbiológicos estabelecidos pela Instrução Normativa 51. Ciência e Tecnologia de Alimentos, v. 25, n. 1, p. 191-195, 2005.

NERO, L. A.; VIÇOSA, G. N.; PEREIRA, F. E. V. Qualidade microbiológica do leite determinada por características de produção. Ciência e Tecnologia de Alimentos, v. 29, n. 2, p. 386-390, 2009.

NETA, F. C. N. Parâmetros de Qualidade em Leite cru refrigerado em propriedades de base familiar na região sul do Espírito Santo. 2013 82f. Dissertação (Mestrado em Ciência e Tecnologia de Alimentos) - Universidade Federal do Espírito Santo, Alegre, 2013. 
OLIVEIRA, C. J. B. et al. Risk factors associated with selected indicators of milk quality in semiarid northeastern Brazil. Journal of Dairy Science, v. 94, n. 6, p. 3166-3175, 2011.

ORTOLANI, M. B. et al. Microbiological quality and safety of raw milk and soft cheese and detection of autochthonous lactic acid bacteria with antagonistic activity against Listeria monocytogenes, Salmonella spp., and Staphylococcus aureus. Foodborne Pathogens and Disease, v. 7, n. 2, p. 175-80, 2010.

PEDRICO, A. et al. Aspectos higiênicossanitários na obtenção do leite no Assentamento Alegre, município de Araguaína, TO. Ciência Animal Brasileira, v. 10, n. 2, p. 610-617, 2009.

PICOLI, T. et al. Level of education of farmers and the characteristics of milk production. Science and Animal Health, v. 2, n. 2, p. 147-159, 2014.

PINTO, C. L. O.; MARTINS, M. L.; VANETTI, M. C. D. Qualidade microbiológica de leite cru refrigerado e isolamento de bactérias psicrotróficas proteolíticas. Ciência e Tecnologia de Alimentos, v. 26, n. 3, p. 645-651, 2006.

RAMOS, M. P. P. et al. Milk production practices on family farms located north of the State of Espírito Santo, Brazil. Journal of Agricultural Science and Technology, v. 3, n. 11, p. 920-926, 2013.

RAMOS, M. P. P. et al. Qualidade microbiológica e fatores que influenciam a produção de leite obtido de propriedades familiares no norte do Estado do Espírito Santo. Revista Brasileira de Agropecuária Sustentável, v. 4, n. 1, p. 1-15, 2014.

SANTOS, M. V.; FONSECA, L. F. L. Estratégias de controle de mastite e melhoria da qualidade do leite. Barueri: Manole, 2007.

SILVA, F. C. N. N. et al. Características de produção de leite cru obtido por ordenha manual em propriedades rurais localizadas no município de São Mateus, ES. Revista do Instituto Laticínios Cândido Tostes, v. 4, n. 371, p. 21-26, 2009.

SILVA, L. C. C. et al. Rastreamento de fontes da contaminação microbiológica do leite cru durante a ordenha em propriedades leiteiras do Agreste Pernambucano. Semina: Ciências Agrárias, v. 32, n. 1, p. 267-276, 2011.

SILVA, M. A. P. Influência dos tipos de ordenha, transporte e tempo de armazenamento na qualidade do leite cru refrigerado da região sudoeste do estado de Goiás. 2008. 60 f. Tese (Doutorado em Produção Animal) - Universidade Federal de Goiás, Goiânia, 2008.

SILVA, M. R. et al. Avaliação higiênicosanitária do leite produzido em Umuarama (Paraná). Boletim do CEPPA, v. 28, n. 2, p. 271-280, 2010.

VICENTE, R. J. Economic efficiency of agricultural production in Brazil. Revista de Economia e Sociologia Rural, v. 42, n. 2, p. 201-222, 2004. 